\title{
Marka Kent Kişiliği: Doğu Karadeniz Şehirleri Üzerine Bir Araştırma
}

\section{Brand City Personality: A Study on The Eastern Black Sea Cities in Turkey}

\author{
Erdem Taşdemir ${ }^{\mathrm{a}}$, Emre Ş. Aslan ${ }^{\mathrm{b}}$, Ali Erkam Yarar, \\ ${ }^{a}$ Prof. Dr., Trabzon Üniversitesi, İletişim Fakültesi, Halkla İlişkiler ve Reklamcılık Bölümü, 61335, Trabzon/Türkiye. \\ ORCID: 0000-0002-9781-4099

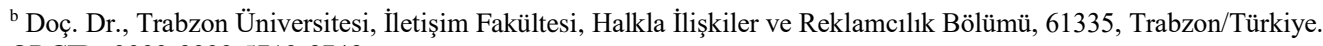 \\ ORCID: 0000-0002-5710-3743
}

${ }^{c}$ Dr. Öğr. Üyesi, Necmettin Erbakan Üniversitesi, Sosyal ve Beşeri Bilimler Fakültesi, Halkla İlişkiler ve Reklamcılık Bölümü, Konya/Türkiye. ORCID: 0000-0002-0919-314X

\section{MAKALE BILLGISI}

\section{Makale Geçmişi:}

Başvuru tarihi: 30 Eylül 2020

Düzeltme tarihi: 02 Şubat 2021

Kabul tarihi: 09 Şubat 2021

\author{
Anahtar Kelimeler: \\ Marka, Kişilik \\ Marka Kent \\ Marka Kent Kişiliği \\ Doğu Karadeniz
}

\section{ARTICLE INFO}

\section{Article history:}

Received 30 September 2020

Received in revised form 02 February 2021

Accepted 09 February 2021

\author{
Keywords: \\ Brand, Personality \\ Brand City \\ Brand City Personality \\ Black Sea.
}

ÖZ

\begin{abstract}
İnsana özgü olan kişilik özelliklerinin, nesnelere de aktarılabilir olmasının bir sonucu olarak ürün, hizmet veya destinasyonlara kişilik özelliği yüklenebilmektedir. Marka olmanın temel unsurlarından olan kişilik özelliklerine sahip olma durumu, çoğunlukla kendiliğinden gelişen, kontrolsüz ve bilinçsiz bir sürecin sonucudur. Hâlbuki markalaşmak isteyen bir destinasyonun atması gereken ilk adımlardan biri iyi düşünülmüş ve planlanmış bir kişilik özelliğine sahip olmaktır. Çoğunlukla kendiliğinden ve rastgele bir şekilde oluşan kişilik özellikleri, insan ile nesne arasındaki etkileşimin temelini oluşturmaktadır. Doğu Karadeniz şehirlerinin marka kent kişilikleri üzerine odaklanan bu çalışma, iç paydaşların kendi şehirleri ile ilgili tutumlarını araştırmayı amaçlamaktadır. Örneklem olarak ele alınan her bir şehir ile ilgili kişilik önerilerinin de sunulduğu bu çalışmadan elde edilen sonuçlara göre, şehirler çok özgün kişilik özelliklerine sahip değillerdir.
\end{abstract}

\section{A B S T R AC T}

Personality traits can be attributed to products, services or destinations as a result of the personality traits peculiar to humans being transferred to objects. Having personality traits, which is one of the basic elements of being a brand, is mostly the result of a spontaneous, uncontrolled and unconscious process. However, one of the first steps for a destination that wants to brand is to have a well-thoughtof and planned personality dimension. This study, which focuses on the brand city personalities of the Eastern Black Sea Cities, aims to investigate the attitudes of internal stakeholders about their cities. According to the results cities do not have very unique personality characteristics. Personality suggestions for each city studied have been developed.

\section{Giriş}

Daha çok tüketicinin zihninde inşa edilen değeri (Aksoy, 2005:40) ifade eden marka kavramı üzerine son yıllarda pek çok çalışma gerçekleştirilmektedir. Özellikle turizmin gelişmesi ve şehirlerin ülkelerin ekonomileri için ürettikleri değerlerin artması, ürün ve hizmet üreticilerinin dışında spor kulüpleri (Ustakara ve Aydemir, 2016:16) ya da destinasyonlar gibi birçok kurumsal yapının markalaşma konularına odaklanmasına neden olmuştur.

Stratejik değeri olan kültürel fikirlerden oluşan markanın (Grant, 2006:55) ortaya çıkabilmesi için kimlik, özgün bir vaat, isim, çağrışım öğeleri ve konumlandırma gibi pek çok unsurun yanında bir de kişiliğe sahip olması gerekmektedir.

\footnotetext{
* Sorumlu yazar/Corresponding author

e-posta:aeyarar@erbakan.edu.tr.
} 
Bir kişinin sahip olduğu sosyal itibar ve içsel doğasıyla bağlantılı bir kavram olan kişiliğin (Taşkın ve Akat, 2008:104) markayla bütünleşmesini sağlayan ve onu marka için bir unsur haline getiren, onun (kişiliğin) ürettiği anlamlardır. Marka sahip olduğu kişilik özellikleriyle çeşitli anlamlar üretmekte ve ürettiği bu anlamları tüketicilere aktarabilmektedir. Markalaşma yolunda mücadele veren şehirlerinde etkili bir marka değeri oluşturabilmeleri için öncelikle iyi planlanmış bir marka kişiliği elde etmeleri gerekmektedir.

Tüm bu görüşler çerçevesinde ele alınan çalışma, Doğu Karadeniz şehirlerinin marka kişiliğine odaklanmaktadır. İç paydaşların yani o şehirde ikamet edenlerin, kendi şehirlerinin marka kent kişilik özelliklerine yönelik tutumlarını ölçmeyi amaçlayan bu çalışma, toplamda 7 ilde uygulanmış ve elde edilen veriler istatistik paket programı aracılığıyla analiz edilmiştir. Frekans analizleri ve tek yönlü varyans analizleri aracılığıyla elde edilen bulgulara göre, araştırmaya konu olan bu şehirlerin kişilik özellikleri birbirleriyle benzerlik göstermektedir.

\section{Marka Kişiliği}

Bir işletmenin gerçekleştirmek istediği en büyük rüyayı somut hale getiren bir değer olarak görülen marka (Bruce ve Harvey, 2010:5), bir organizasyon, hizmet ya da ürünün sağladığ edilmektedir (Buckingham, 2011:1). Marka; akılc1 ve somut, duygusal veya sembolik değerlerden oluşan ve aynı zamanda üründen veya hizmetten farklılaşan boyutlara sahiptir (Keller, 2008:5). Daha geniş anlamda markayı alıcı ve satıcısı olan, ayırt edici bir isim, simge veya tescile sahip olan, tüketicilerin zihinlerinde olumlu veya olumsuz izlenimler uyandıran, yaratılmış bir şey olarak tanımlamak mümkündür (Morgan, 2001:52-53). Dolayısıyla markayı sadece kutunun üzerindeki isim olarak görmek, taşıdığı derin anlamlar açısından haksızlık olur. Çünkü o, birçok duygu, düşünce, imaj, tarih, ihtimaller ve hatta firma hakkında dolaşan dedikodulardan oluşan bir değer olarak ifade edilmektedir (Sullivan, 2004:33). Marka ile ilgili dile getirilen yukarıdaki görüşler dikkatle incelendiğinde markanın tek boyutlu olmadığı ve birçok boyuta sahip olduğu dile getirilebilir. Tüketicinin ihtiyaçlarını gidermede tatmin sağlayan, statü göstergesi olan, soyut ve duygusal bileşenlere sahip olan ve beynin duygusal tarafina hitap eden marka (Kirdar, 2003:234), hem somut hem de soyut değerlerden oluşması nedeniyle çok daha fazla değişken ile ilişkilidir. $\mathrm{Bu}$ değişkenleri; kişilik, kimlik, imaj, çağrışım öğeleri, logo, slogan, sembol, renk, maskot vs. olarak sıralamak mümkündür.

Tüketici tercihlerini yönlendirmenin güçleştiği, karmaşık bir pazar ve rekabet ortamının ortaya çıktığı günümüzde (Uztuğ, 2003:20) markalar, tüketicilerin ortak algısı içerisinde tanımlanan bir kişilik ve kimlik olarak görülmektedirler. Günümüzde insanların markalara, bir insanmış gibi veya insan olmaları halinde kendilerini etkileyebilecek kişilik özelliklerine sahip varlıklarmış gibi baktıkları bir gerçektir (Pringle ve Thompson, 2000:56-57). Bazı tüketiciler için marka, dertleşilebilen, paylaşımda bulunulabilen, ortak zevkler ve heyecanlar yaşanılabilen bir kişiye dönüşmüş durumdadır (Aslan, 2014:20). Markanın bir insanmış gibi (modern, geleneksel, düzenli, agresif vb.) görülmesini ve markaya psikolojik özellikler yüklenmesini sağlayan ana unsur, marka kişiliğidir (Tosun, 2010:89).

Latince personae kelimesinden gelen ve insanın dış dünyaya sunulan ifadesi olarak tanımlanabilen kişilik (personality), bireyin iç ve dış çevresiyle kurduğu, ayırt edici, tutarlı ve yapılanmış bir ilişkiler biçimi olarak da ifade edilmektedir (Koç, 2011:226). Müşterilerin kalplerinde ve zihinlerinde yaşadığına ve bir yaşam biçimi olduğuna inanılan markaların (Moon ve Millison, 2003:31) sahip olduğu kişilikler, markaların dış dünyaya sunmak istedikleri şeylerin ayırt edici, tutarlı ve yapılandırılmış ilişkiler biçimi veya ifadesi olarak değerlendirilmektedir.

Markaya daha çok sembolik anlatımlar ve soyut tanımlamalar kazandıran marka kişiliği (Elden, 2009:113), yerine getirilmemiş vaatlerden ve farklı değer kümelerinden oluşması nedeniyle diğer tüm kişilikler gibi benzersizdir (Pile, 2001:242). Bu özelliği ile de benzer ürün/hizmet pazarlarında farklılaşma ihtiyacının ortaya çıkmasını sağlar (Aaker ve Joachimsthaler, 2000:53). Bir markanın dostane mi, soğuk mu, asık suratlı mı, güler yüzlü mü, arkadaş canlısı mı, güvenilir mi? vb. olup olmadığını ifade eden cansız ürün ve hizmetler için kullanılan bu ifadeler (Pringle ve Thompson, 2000:57), markaların kişilik özelliklerini ortaya koymaktadır.

Markanın hatırlanmasını, ilgi çekmesini, marka ile tüketici arasındaki arkadaşlık ve danışmanlık gibi ilişkilerin ortaya çıkmasını sağlama potansiyeline sahip olan marka kişiliği, (Aaker ve Joachimsthaler, 2000:53) Henry'ye göre (2001:175) gerçekte satılan değerin adıdır. Markaların ortak özelliği olarak görülen güçlü kişilik (Borça, 2007:42), oluşturduğu duygusal çağrışımlarla marka-tüketici ilişkisini güçlendirebilmektedir (Erdil ve Uzun, 2009:98). Marka kişiliğinin tüketici üzerindeki bu etkisinin farkında olan işletmeler, markalarını inşa ederken öncelikle marka kişiliğini belirleme yoluna gitmektedirler. Marka inşasının temelinde yer alan önce kişiliği belirleme yaklaşımı, hem marka-tüketici arasındaki ilişkiyi güçlendirme hem de markayı farklılaştıracak öğeleri kazandırma amacını taşımaktadır.

Marka kişiliği üzerine gerçekleştirilen çalışmalar incelendiğinde, birçok farklı kişilik özelliğinin belirlendiği görülmektedir. Jenniffer L. Aaker (1997) çalışmasında toplamda 42 kişilik özelliğine yer verirken bu kişilik özelliklerini önce 15 bölümde ardından ise beş temel boyutta özetlemektedir.

Aaker'in bu bölümlemesinin yanında başka bir araştırmacı tarafından marka kişilik özelliklerinin 12 bölümde yine beş farklı boyutta ele alındığı (Geuens vd., 2009:103) görülmektedir. Dolayısıyla marka kişiliği ile ilgili özelliklerin araştırmacılara göre değişkenlik gösterdiği ifade edilebilir. 


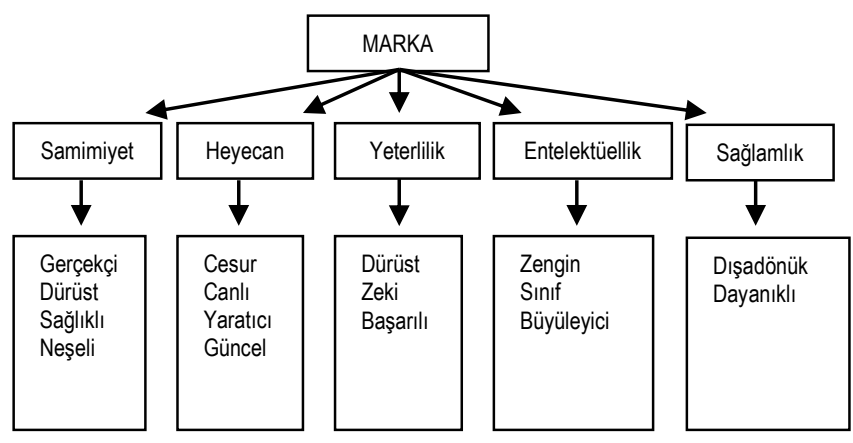

Şekil 1.Marka Kişiliği Çerçevesi (Aaker, 1997).

\section{Marka Kent Kişiliği}

Markanın sadece bir isim olarak görülemeyeceği gerçektir. Çünkü o, birçok duygudan, düşünceden, imajdan, tarihi birikimden, ihtimallerden ve işletme hakkında dolaşan dedikodulardan oluşmaktadır. (Sullivan, 2004:33). Şehirlerde, bir marka haline gelirken sadece isimleriyle değil, hedef kitlelerine verdikleri duyguların, inşa ettikleri düşüncelerin, sahip oldukları imajların, tarihi birikimlerin, geleceğe yönelik barındırdıkları ihtimallerin, verdikleri sözlerin ve haklarında dolaşan dedikoduların toplamıyla şekillenmektedirler. Tüm bunlar, şehirlere bilinçli veya bilinçsiz bir şekilde kişilik kazandırmaktadır.

Şehirlerarasında seyahat eden bir birey, karayolunda ilerlerken biri diğerine benzeyen çok sayıda yerleşime rastlayabilmektedir (İlgüner ve Asplund, 2011:247). Benzerlerin bir arada yer aldığı bir ortamda, daha önce deneyimlenmiş bir gerçekliğin yeniden deneyimlenmesini istemek özellikle günümüz insanı için yeterince cezbedici değildir. Urry'nin (2009:32) de vurguladığ1 gibi turist bakışının potansiyel bir nesnesi haline gelebilmek için farklı olmak yani sıradan olanın, benzer olanın dışında olmak gerekmektedir. Çünkü insanlar, bir turistik faaliyet gerçekleştirirken gündelik yaşamlarında genelde karşılaştıklarından farklı ölçekte, farklı duyguları içeren hazları deneyimlemeyi istemektedirler. $\mathrm{Bu}$ isteğe verilen cevap, bir yerin çekici olmasını veya olmamasını belirlemektedir.

İnsanlar için ideal olanı veya istenen tatmin düzeyini temsil ettiği düşünülen markanın (Moon ve Millison, 2003:30) değer katabilen, bağlılık yaratabilen, yenilikçiliği özendirebilen ve büyümede aktif rol oynayabilen bir varlık (Bruce ve Harvey, 2010:4) haline gelebilmesi; ürünün, hizmetin veya şehrin özgün kimliğinin (İlgüner ve Asplund, 2011:221) ve kişiliğinin ortaya konulmasına bağlıdır.

Markaya yüklenen kişiliğin hedef kitlede belli çağrışımların oluşturulmasında oldukça etkili olduğu bir gerçektir (Tosun, 2010:89). Bu nedenle bir şehrin markalaştırılması isteniyorsa öncelikle kişiliğinin belirlenmesi gerekmektedir. Yani şehir nasıl bir kişiliğe sahip olacak; modern mi yoksa geleneksel mi, enerjik mi yoksa durağan mı, karizmatik mi yoksa sempatik mi? Belirlenecek olan kişilik özellikleri aynı zamanda şehrin turistler ve şehir sakinleri tarafindan nasıl algılanacağını ve nasıl bir imaja sahip olacağını da ortaya koyacaktır.

Bir şehir için marka kişiliğini belirlemek tek başına yeterli değildir. Bu kişiliğin kendi içerisinde tutarlı olmasına da dikkat edilmesi gerekmektedir. Kişilik tutarlılığının başarılı bir marka inşa etmede temel konulardan biri olması (Pringle ve Thompson, 2000:88), şehrin yöneticilerinin ve şehrin marka inşacılarının da şehrin kişilik özelliklerini belirlerken tutarlılık ilkesini dikkate almalarını zorunlu kılmaktadır. Daha açık bir ifadeyle bir şehir için marka kent kişiliği belirlenirken kavramların birbirleriyle çelişmemesi gerekmektedir. Örneğin, bir şehir hem yaşlı hem de genç, hem modası geçmiş hem de çağdaş bir kent olamaz. Çünkü bu kavramlar birbirlerinin zıttıdır ve şehir ile ilgili net bir algının oluşmasını engelleyebilir.

\section{Araștırma}

\subsection{Araştırmanın Amacı}

Şehirlerin markalaşabilmesinde kişilik özelliklerinin belirlenmesi oldukça önemli bir stratejik hamle olarak görülmektedir. Bu araştırma çerçevesinde Doğu Karadeniz Bölgesi'nde yer alan şehirlerin marka kişiliğine yönelik tutumların neler olduğunu ortaya koyma ve bölge şehirlerinin markalaşma süreçlerine katkıda bulunma amacı güdülmektedir. Böylece Doğu Karadeniz şehirlerinin markalaşma süreçlerine katkıda bulunulmuş olacaktır.

\subsection{Araştırmanın Önemi}

Kentlerin markalaşması üzerine pek çok çalışma bulunmasına rağmen şehirlerin marka kişilikleri üzerine çok az çalışma bulunmaktadır. Bu çalışma Doğu Karadeniz Bölgesi'nde yer alan şehirlerin marka kişilikleri üzerine gerçekleştirilen ilk çalışmalardan biri olması ve aynı zamanda o şehirlerde yaşayan sakinlerin kendi şehirlerinin kişilikleri ile ilgili tutumlarını ölçen ilk çalışmalardan biri olması nedeniyle önem arz etmektedir.

\subsection{Araştırmanın Hipotezleri}

Bu çalışmanın hipotezleri aşağıdaki gibi belirlenmiştir.

H1. Şehirlerin marka kişilikleri ile ilgili tutumlar cinsiyet değişkenine göre farklılık göstermektedir.

H2. Şehirlerin marka kişilikleri ile ilgili tutumlar eğitim durumu değişkenine göre farklılık göstermektedir.

H3. Şehirlerin marka kişilikleri ile ilgili tutumlar yaş değişkenine göre farklılık göstermektedir.

\subsection{Araştırmanın Evren ve Örneklemi}

Şehirlerin marka kişiliklerine yönelik tutumlar üzerine odaklanan bu çalışmanın evrenini Doğu Karadeniz Bölgesi'nde yaşayan bireyler oluşturmaktadır. Doğu Karadeniz Belediyeler Birliği'ne bağlı şehirlerin (Artvin, Bayburt, Giresun, Gümüşhane, Ordu, Trabzon ve Rize) evren olarak alındığı bu araştırma, iç markalaşma çerçevesinde Mayıs 2017 ve Temmuz 2019 tarihleri arasında araştırmacılar tarafından yüz yüze uygulanmıştır. Araştırma örneklemi, Doğu Karadeniz şehirlerinde ikamet eden 18 yaşından büyük, en az okur yazar olan ve şehirleri hakkında fikir beyan edebilecek kadın ve erkekler üzerinde gerçekleştirilmiştir

\subsection{Araştırmanın Kapsam ve Sınırlılıkları}

$\mathrm{Bu}$ araştırma, Doğu Karadeniz Belediyeler Birliği üyesi şehirlerde ikamet eden kent sakinleriyle sınırlandırılmıştır. Doğu Karadeniz İlleri kapsamına giren şehir merkezlerinde gerçekleştirilen bu araştırmada örneklem büyüklükleri, şehirlerin nüfus bakımından büyüklüğüne göre 
belirlenmiştir. Gerçekleştirilen araştırma planlamasına göre; Trabzon ve Ordu'da 270, Rize ve Giresun'da 200, Gümüşhane, Artvin ve Bayburt'ta ise 125 'e anket uygulanmıştır. Toplamda 1.315 anketin uygulandığı bu araştırmada hatalı olduğu veya ciddiyetle doldurulmadığ gözlemlenen anketler çıkarılmış ve geriye kalan 1.221 anket analize tabi tutulmuştur.

\subsection{Araştırmanın Yöntemi}

$\mathrm{Bu}$ araştırmada anket tekniğiyle toplanan veriler bir paket istatistik programına girilmiş ve bu programa girilen veriler, frekans, $\mathrm{t}$ testi ve tek yönlü varyans analizine tabi tutulmuştur.

\subsection{Verilerin Analizi ve Bulgular}

\subsubsection{Demografik Verilerin Analizi}

Doğu Karadeniz şehirlerinde ikamet edenlerin kendi şehirlerinin kişiliğine yönelik tutumları araştırılırken araştırmaya katılanların demografik özellikleri aşağıdaki gibidir.

Tablo 1. Yaş ve Eğitim Durumu Frekans Analizi

\begin{tabular}{|c|c|c|c|c|c|}
\hline \multicolumn{3}{|c|}{ Yaş Durumu } & \multicolumn{3}{|c|}{ Eğitim Durumu } \\
\hline & Frekans & Yüzde & & Frekans & Yüzde \\
\hline $18-27$ & 459 & 37,6 & İlkokul & 116 & 9,5 \\
\hline $28-37$ & 398 & 32,6 & Ortaokul & 78 & 6,4 \\
\hline $38-47$ & 192 & 15,7 & Lise & 371 & 30,4 \\
\hline $48-57$ & 120 & 9,8 & Ön lisans & 320 & 26,2 \\
\hline $\begin{array}{ll}58 & \text { ve } \\
\text { üzeri } & \end{array}$ & 33 & 2,7 & Lisans & 294 & 24 \\
\hline $\begin{array}{l}\text { Kayıp } \\
\text { veri }\end{array}$ & 19 & 1,6 & Lisansüstü & 24 & 2,0 \\
\hline TOPLAM & 1221 & 100 & Kayıp veri & 18 & 1,5 \\
\hline & & & TOPLAM & 1221 & 100 \\
\hline
\end{tabular}

Araştırmaya katılan denekler, yaş ve eğitim durumu açısından analiz edildiğinde katılımcıların \%37,6'sının 1827 yaş aralığında, \%32,6'sının ise 28-37 yaş aralığında olduğu görülmektedir. Eğitim durumu açısından katılımcılar incelendiğinde ise en fazla katılımın lise $(\% 30,4)$, ön lisans $(\% 26,2)$ ve lisans $(\% 24)$ düzeyindeki kişiler tarafından sağlandığı anlaşılmaktadır.

Tablo 2. Cinsiyet ve Medeni Duruma İlişkin Frekans Analizi

Cinsiyet Durumu

Medeni Durum

\begin{tabular}{llllll}
\hline & Frekans & Yüzde & & Frekans & Yüzde \\
\hline Kadın & 539 & 44,1 & Evli & 617 & 50,5 \\
\hline Erkek & 672 & 55,0 & Bekâr & 591 & 48,4 \\
\hline Kayıp veri & 10 &, 8 & Kayıp veri & 13 & 1,1 \\
\hline TOPLAM & $\mathbf{1 2 2 1}$ & $\mathbf{1 0 0}$ & TOPLAM & $\mathbf{1 2 2 1}$ & $\mathbf{1 0 0}$
\end{tabular}

$\mathrm{Bu}$ çalışmaya katkıda bulunan deneklerin \%55'ini erkeklerin, \%44,1'ini kadınların, \%50,5'ini evlilerin, \%48,4'ünü ise bekarların oluşturduğu ortaya çıkmaktadır.

Araştırmanın katılımcıları gelir durumları açısından büyük oranda 2.501 TL ile 5.000 TL arasında bir gelire sahip
$(\% 37,4)$ kişilerden oluşurken $2.500 \mathrm{TL}$ ve altında geliri olan katılımcılar $(\% 30,4)$ en büyük orana sahip ikinci grubu oluşturmaktadır.

Katılımcılar mesleki yapıları açısından incelendiğinde en fazla katılım sağlayan meslek gruplarını ise öğrenciler $(\% 14,7)$, memurlar $(\% 11,5)$, ev hanımları $(\% 10,1)$ olarak siralamak mümkündür.

Tablo 3. Gelir Durumu Frekans Analizi

Gelir Durumu

\begin{tabular}{lll}
\hline & Frekans & Yüzde \\
\hline $\mathbf{2 5 0 0}$ TL ve altı & 371 & 30,4 \\
\hline $\mathbf{2 5 0 1 - 5 0 0 0}$ TL & 457 & 37,4 \\
\hline $\mathbf{5 0 0 1 - 7 5 0 0 ~ T L}$ & 47 & 3,8 \\
\hline $\mathbf{7 5 0 1 - 1 0 0 0 0 ~ T L}$ & 43 & 3,5 \\
\hline $\mathbf{1 0 0 0 1}$ ve üzeri & 8 &, 7 \\
\hline Kayı veri & 295 & 24,2 \\
\hline TOPLAM & $\mathbf{1 2 2 1}$ & $\mathbf{1 0 0}$
\end{tabular}

Tablo 4. Mesleki Duruma İlișkin Frekans Analiz

Mesleki Durum

\begin{tabular}{|c|c|c|c|c|c|}
\hline & Frekans & Yüzde & & Frekans & Yüzde \\
\hline Akademisyen & 18 & 1,5 & Așçı & 5 & , 4 \\
\hline Avukat & 3 & ,2 & Bankacı & 14 & 1,1 \\
\hline Bilişimci & 7 & 6 & Çiftçi & 6 & 5 \\
\hline Danışman & 6 & 6 & Doktor & 4 & , 3 \\
\hline Eczacı & 4 & ,3 & Eğitimci & 5 & 4 \\
\hline Ekonomist & 6 & 5 & Elektrikçi & 13 & 1 \\
\hline Emekli & 34 & 2,8 & Esnaf & 116 & 9,5 \\
\hline Ev hanımı & 123 & 10,1 & Garson & 8 & ,7 \\
\hline $\begin{array}{l}\text { Güvenlik } \\
\text { Görevlisi }\end{array}$ & 15 & 1,2 & İlahiyatçı & 5 & ,4 \\
\hline İletişimci & 16 & 1,3 & İş adamı & 12 & 1,0 \\
\hline İş̧̧i & 91 & 7,5 & İşsiz & 17 & 1,4 \\
\hline Kasiyer & 8 & ,7 & Memur & 141 & 11,5 \\
\hline Mimar & 5 &, 4 & Muhasebe & 16 & 1,3 \\
\hline Mühendis & 29 & 2,4 & Müteahhit & 4 & ,3 \\
\hline Öğrenci & 179 & 14,7 & Öğretmen & 61 & 5,0 \\
\hline Pazarlamacı & 21 & 1,7 & PDR & 3 &, 2 \\
\hline Sağlıkçıı & 35 & 2,9 & Sekreter & 12 & 1,0 \\
\hline $\begin{array}{l}\text { Serbest } \\
\text { Meslek }\end{array}$ & 38 & 3,1 & Şoför & 16 & 1,3 \\
\hline Tekniker & 27 & 2,2 & Turizmci & 5 & 4 \\
\hline Usta & 18 & 1,5 & Uzman & 13 & 1 \\
\hline Yönetici & 9 &, 7 & $\begin{array}{l}\text { Kayıp } \\
\text { Veri }\end{array}$ & 53 & 4,4 \\
\hline
\end{tabular}


Tablo 5. İkamet Edilen Şehir ile İlgili Frekans Analizi

İkamet Edilen Şehir Durumu

\begin{tabular}{lll}
\hline & Frekans & Yüzde \\
\hline Artvin & 124 & 10,2 \\
\hline Bayburt & 110 & 9,0 \\
\hline Giresun & 168 & 13,7 \\
\hline Gümüşhane & 129 & 10,6 \\
\hline Ordu & 240 & 19,6 \\
\hline Rize & 177 & 14,5 \\
\hline Trabzon & 273 & 22,4 \\
\hline TOPLAM & $\mathbf{1 2 2 1}$ & $\mathbf{1 0 0}$
\end{tabular}

Araştırmaya katılanlar, şehir bazında incelendiğinde \%22,4'ünün Trabzon'da, \%19,7'sinin Ordu'da, \%14,5'inin Rize'de, \%13,8'inin Giresun'da, \%10,6'sinın Gümüşhane'de, \%10,2'sinin Artvin'de ve \%9'unun ise Bayburt'ta ikamet eden kadın ve erkeklerden oluştuğu ortaya çıkmaktadır. Şehirlerden örneklem alınırken şehirlerin nüfus yapıları göz önüne alınarak araştırma planlanmıştır.

\subsubsection{Doğu Karadeniz Marka Kent Kişiliği Ille İlgili Genel Tutumlar}

$\mathrm{Bu}$ araştırma çerçevesinde ilk sorulan sorulardan biri marka kent kişiliğini ölçmeyi amaçlamaktadır. Aaker'in (1997) ve Geuens ve arkadaşlarının (2009:103) marka kişiliği ölçeklerinin kentlere uyarlanmasıyla hazırlanan bu ölçekte, bazı kişilik özelliklerinin kentlerle uyumlu olmaması araştırmacılar tarafından kararlaştırılmış ve kapsam dışı tutulmuştur. Ayrıca, araştırmacılar faydalı olacağını düşündükleri kişilik özelliklerini eklemiş ve 55 maddelik kişilik özelliğine ölçekte yer verilmiştir. Ayrıca 56. madde olarak diğer şıkkının da yer aldığı ölçekte, verilen cevaplar içerisinde en yüksek frekansa sahip olan kişilik özelliklerine Tablo 6'da yer verilmektedir. Katılımcilardan, ikamet etmekte oldukları şehirlerini en iyi şekilde tanımladığını düşündükleri beş kişilik özelliğini seçmeleri ve bu seçtikleri kişilik özelliklerini en önemliden daha az önemliye olacak şekilde sıralamaları istenmiştir.

Tablo 6'da deneklerin birinci, ikinci, üçüncü, dördüncü ve beşinci sırada verdikleri cevapların frekans tablolarına yer verilmektedir. Bu tabloda yer alan verilere göre, denekler genel olarak Doğu Karadeniz şehirlerinin Kişiliğini birinci sırada aileye yönelik $(\% 24,7)$, küçük kent $(\% 18,7)$, geleneksel $(\% 8,4)$, güvenilir $(\% 4,6)$ ve huzurlu $(\% 4,5)$ bulmaktadırlar. İkinci sırada yer alan kişilik tercihlerine göre ise denekler, Doğu Karadeniz şehirlerini küçük kent $(\% 11,2)$, geleneksel $(\% 8,5)$, güvenilir $(\% 6,6)$, emniyetli $(\% 5,6)$ ve aileye yönelik $(\% 4,9)$ bir kent olarak değerlendirmektedirler.
Tablo 6. Doğu Karadeniz Marka Kent Kișiliği İle İlgili Genel Tutumların Frekans Analizi

\begin{tabular}{|c|c|c|c|c|c|c|c|c|c|c|}
\hline & \multicolumn{2}{|c|}{$\begin{array}{l}\text { BIRINCCi } \\
\text { SIRA }\end{array}$} & \multicolumn{2}{|c|}{$\begin{array}{l}\text { İKINCI } \\
\text { SIRA }\end{array}$} & \multicolumn{2}{|c|}{$\begin{array}{l}\text { ÜÇÜNC } \\
\text { Ü SIRA }\end{array}$} & \multicolumn{2}{|c|}{$\begin{array}{l}\text { DÖRDÜN } \\
\text { Cü SIRA }\end{array}$} & \multicolumn{2}{|c|}{$\begin{array}{l}\text { BESSINCI } \\
\text { SIRA }\end{array}$} \\
\hline & f & $\%$ & f & $\%$ & f & $\%$ & $\mathbf{f}$ & $\%$ & $\mathbf{f}$ & $\%$ \\
\hline $\begin{array}{c}\text { Aileye } \\
\text { Yönelik } \\
\end{array}$ & 302 & 24,7 & 60 & 4,9 & 39 & 3,2 & 37 & 3,0 & 42 & 3,4 \\
\hline $\begin{array}{l}\text { Küçüik } \\
\text { Kent }\end{array}$ & 228 & 18,7 & 137 & 11,2 & 47 & 3,8 & 45 & 3,7 & 42 & 3,4 \\
\hline Geleneksel & 102 & 8,4 & 104 & 8,5 & 80 & 6,6 & 37 & 3,0 & 35 & 2,9 \\
\hline Açık Sözlü & 42 & 3,4 & 49 & 4,0 & 32 & 2,6 & 28 & 2,3 & 14 & 1,1 \\
\hline Gerçekçi & 10 & ,8 & 16 & 1,3 & 10 & ,8 & 10 &, 8 & 17 & 1,4 \\
\hline $\begin{array}{c}\text { Düşünce } \\
\text { Sahibi }\end{array}$ & 12 & 1,0 & 5 & ,4 & 6 &, 5 & 2 &, 2 & 4 &, 3 \\
\hline Özenli & 8 & ,7 & 4 & ,3 & 4 &, 3 & 2 &, 2 & 6 &, 5 \\
\hline Özgün & 24 & 2,0 & 36 & 2,9 & 17 & 1,4 & 21 & 1,7 & 13 & 1,1 \\
\hline Yaşlı & 15 & 1,2 & 25 & 2,0 & 18 & 1,5 & 13 & 1,1 & 18 & 1,5 \\
\hline Klasik & 13 & 1,1 & 29 & 2,4 & 23 & 1,9 & 37 & 3,0 & 23 & 1,9 \\
\hline $\begin{array}{l}\text { Modası } \\
\text { Geçmiş }\end{array}$ & 7 & ,6 & 27 & 2,2 & 22 & 1,8 & 18 & 1,5 & 8 & ,7 \\
\hline Duygusal & 6 &, 5 & 13 & 1,1 & 16 & 1,3 & 9 &, 7 & 5 & ,4 \\
\hline Dostça & 22 & 1,8 & 50 & 4,1 & 53 & 4,3 & 47 & 3,8 & 31 & 2,5 \\
\hline Sicak & 26 & 2,1 & 40 & 3,3 & 59 & 4,8 & 48 & 3,9 & 47 & 3,8 \\
\hline Mutlu & 24 & 2,0 & 45 & 3,7 & 51 & 4,2 & 27 & 2,2 & 28 & 2,3 \\
\hline $\begin{array}{l}\text { Trend } \\
\text { Takip } \\
\text { Eden }\end{array}$ & 4 &, 3 & 15 & 1,2 & 12 & 1,0 & 7 &, 6 & 8 &, 7 \\
\hline $\begin{array}{c}\text { Heyecan } \\
\text { Verici }\end{array}$ & 7 & ,6 & 18 & 1,5 & 8 &, 7 & 8 &, 7 & 12 & 1,0 \\
\hline Olağandışı & 9 &, 7 & 14 & 1,1 & 8 &, 7 & 5 &, 4 & 7 &, 6 \\
\hline Parlak & 3 & ,2 & 7 & 6 & 2 &, 2 & 5 &, 4 & 3 &, 2 \\
\hline Kışkırtıcı & 1 & , 1 & 13 & 1,1 & 9 &, 7 & 5 &, 4 & 3 &, 2 \\
\hline $\begin{array}{c}\text { Cool- } \\
\text { Karizmatik }\end{array}$ & 3 & ,2 & 2 & ,2 & 6 &, 5 & 3 &, 2 & 2 &, 2 \\
\hline Genç & 10 & ,8 & 19 & 1,6 & 16 & 1,3 & 4 &, 3 & 1 &, 1 \\
\hline $\begin{array}{l}\text { Yaşam } \\
\text { Dolu }\end{array}$ & 17 & 1,4 & 43 & 3,5 & 46 & 3,8 & 26 & 2,1 & 18 & 1,5 \\
\hline Maceracı & 10 & ,8 & 11 & ,9 & 21 & 1,7 & 21 & 1,7 & 9 &, 7 \\
\hline Eşsiz & 15 & 1,2 & 10 &, 8 & 22 & 1,8 & 14 & 1,1 & 9 &, 7 \\
\hline Şakacı & 13 & 1,1 & 19 & 1,6 & 33 & 2,7 & 33 & 2,7 & 15 & 1,2 \\
\hline Şaşırtıcı & 2 & ,2 & 6 &, 5 & 18 & 1,5 & 19 & 1,6 & 4 &, 3 \\
\hline Artistik & 1 & , 1 & 3 & ,2 & 7 & ,6 & 10 &, 8 & 5 &, 4 \\
\hline Eğlenceli & 10 & ,8 & 21 & 1,7 & 47 & 3,8 & 31 & 2,5 & 22 & 1,8 \\
\hline Bağımsız & 2 & ,2 & 10 & ,8 & 16 & 1,3 & 23 & 1,9 & 15 & 1,2 \\
\hline Çağdaş & 13 & 1,1 & 11 & ,9 & 17 & 1,4 & 13 & 1,1 & 12 & 1,0 \\
\hline Yenilikçi & 3 & ,2 & 10 & 8 & 14 & 1,1 & 8 &, 7 & 10 &, 8 \\
\hline Atılgan & 1 &, 1 & 11 & ,9 & 9 &, 7 & 14 & 1,1 & 13 & 1,1 \\
\hline Çalışkan & 24 & 2,0 & 28 & 2,3 & 43 & 3,5 & 51 & 4,2 & 33 & 2,7 \\
\hline Emniyetli & 46 & 3,8 & 68 & 5,6 & 83 & 6,8 & 94 & 7,7 & 37 & 0 \\
\hline
\end{tabular}




\begin{tabular}{|c|c|c|c|c|c|c|c|c|c|c|}
\hline Yeterli & 1 &, 1 & 6 &, 5 & 9 &, 7 & 8 &, 7 & 7 & 6 \\
\hline Güvenilir & 56 & 4,6 & 81 & 6,6 & 79 & 6,5 & 130 & 10,6 & 68 & 5,6 \\
\hline Dikkatli & - & - & 1 & ,1 & 4 &, 3 & 6 &, 5 & 6 &, 5 \\
\hline Teknik & 1 &, 1 & - & - & 2 &, 2 & 1 & ,1 & 1 & ,1 \\
\hline $\begin{array}{c}\text { Kurumsall } \\
\text { aşmış }\end{array}$ & - & - & 1 &, 1 & 3 &, 2 & 6 &, 5 & 5 & ,4 \\
\hline Ciddi & - & - & 4 &, 3 & 10 & ,8 & 13 & 1,1 & 16 & 1,3 \\
\hline Lider & 2 &, 2 & 5 & ,4 & 10 &, 8 & 11 & ,9 & 14 & 1,1 \\
\hline Özgüvenli & 10 & ,8 & 17 & 1,4 & 21 & 1,7 & 27 & 2,2 & 47 & 3,8 \\
\hline Etkileyici & 3 & ,2 & 7 & ,6 & 17 & 1,4 & 23 & 1,9 & 15 & 1,2 \\
\hline $\begin{array}{c}\text { Göz } \\
\text { Kamaştırıc } \\
\mathbf{l}\end{array}$ & 6 &, 5 & 7 & 6 & 8 &, 7 & 18 & 1,5 & 9 &, 7 \\
\hline Güzel & 26 & 2,1 & 37 & 3,0 & 29 & 2,4 & 61 & 5,0 & 87 & 7,1 \\
\hline Gösteriş̧li & - & - & 8 &, 7 & 9 &, 7 & 19 & 1,6 & 29 & 2,4 \\
\hline İncelikli & 1 &, 1 & 4 &, 3 & 7 & 6 & 4 &, 3 & 5 &, 4 \\
\hline Latif & - & - & - & - & 2 &, 2 & 1 &, 1 & 5 &, 4 \\
\hline Atletik & - & - & - & - & - & - & 2 &, 2 & 4 &, 3 \\
\hline Sağlam & 5 &, 4 & 4 &, 3 & 9 &, 7 & 15 & 1,2 & 32 & 2,6 \\
\hline Güçlü & 8 &, 7 & 9 &, 7 & 11 & ,9 & 20 & 1,6 & 36 & 2,9 \\
\hline Saçma & 5 &, 4 & 4 & ,3 & 6 &, 5 & 19 & 1,6 & 39 & 3,2 \\
\hline Huzurlu & 55 & 4,5 & 39 & 3,2 & 68 & 5,6 & 57 & 4,7 & 187 & 15,3 \\
\hline Diğer & 5 & ,4 & 1 &, 1 & - & - & - & - & 12 & 1,0 \\
\hline Kayıp Veri & 2 &, 2 & 3 &, 2 & 3 &, 2 & 5 &, 4 & 26 & 2,1 \\
\hline TOPLAM & 1221 & 100 & 1221 & 100 & $\begin{array}{l}12 \\
21\end{array}$ & 100 & 1221 & 100 & 1221 & 100 \\
\hline
\end{tabular}

Tablo 7. Artvin Marka Kent Kişiliğine Yönelik Tutumlar

\begin{tabular}{|c|c|c|c|c|c|c|c|c|c|c|}
\hline & \multicolumn{2}{|c|}{$\begin{array}{l}\text { BİRINCI } \\
\text { SIRA }\end{array}$} & \multicolumn{2}{|c|}{$\begin{array}{l}\text { ÍKINCI } \\
\text { SIRA }\end{array}$} & \multicolumn{2}{|c|}{$\begin{array}{l}\text { ÜÇÜNC } \\
\text { Ü SIRA }\end{array}$} & \multicolumn{2}{|c|}{$\begin{array}{l}\text { DÖRD } \\
\text { ÜNCÜ } \\
\text { SIRA }\end{array}$} & \multicolumn{2}{|c|}{$\begin{array}{l}\text { BEŞINC } \\
\text { İ SIRA }\end{array}$} \\
\hline & $\mathbf{f}$ & $\%$ & $\mathbf{f}$ & $\%$ & $\mathbf{f}$ & $\%$ & $\mathbf{f}$ & $\%$ & $\mathbf{f}$ & $\%$ \\
\hline $\begin{array}{l}\text { Aileye } \\
\text { Yönelik }\end{array}$ & 29 & 23,4 & 3 & 2,4 & 7 & 5,6 & 1 & ,8 & 3 & 2,4 \\
\hline $\begin{array}{l}\text { Küçük } \\
\text { Kent }\end{array}$ & 27 & 21,8 & 22 & 17,7 & 6 & 4,8 & 11 & 8,9 & 13 & 10,5 \\
\hline Geleneksel & 6 & 4,8 & 6 & 4,8 & 8 & 6,5 & 8 & 6,5 & 1 & 8 \\
\hline Açık Sözlü & 2 & 1,6 & 6 & 4,8 & 2 & 1,6 & 4 & 3,2 & 1 & 8 \\
\hline Yaşlı & 3 & 2,4 & 6 & 4,8 & 2 & 1,6 & 2 & 1,6 & 3 & 2,4 \\
\hline Dostça & 1 &, 8 & 5 & 4,0 & 4 & 3,2 & 8 & 6,5 & 3 & 2,4 \\
\hline Sicak & 2 & 1,6 & 4 & 3,2 & 6 & 4,8 & 5 & 4,0 & 7 & 5,6 \\
\hline Mutlu & 3 & 2,4 & 5 & 4,0 & 8 & 6,5 & 4 & 3,2 & 4 & 3,2 \\
\hline Emniyetli & 7 & 5,6 & 9 & 7,3 & 16 & 12,9 & 11 & 8,9 & 5 & 4,0 \\
\hline Güvenilir & 8 & 6,5 & 16 & 12,9 & 13 & 10,5 & 12 & 9,7 & 12 & 9,7 \\
\hline Güzel & 5 & 4,0 & 6 & 4,8 & 3 & 2,4 & 5 & 4,0 & 15 & 12,1 \\
\hline Huzurlu & 7 & 5,6 & 9 & 7,3 & 13 & 10,5 & 5 & 4,0 & 24 & 19,4 \\
\hline
\end{tabular}

Katılımcıların Artvin şehri ile ilgili verdikleri cevaplar analiz edildiğinde elde edilen verilere göre ilk tercihlerde en fazla ön plana çıkan kişilik özelliklerinin aileye yönelik $(\% 23,4)$, küçük kent $(\% 21,8)$, güvenilir $(\% 6,5)$, emniyetli $(\% 5,6)$ ve huzurlu $(\% 5,6)$ olduğu görülmektedir. İkinci sıra tercihlerine göre küçük kent $(\% 17,7)$, güvenilir $(\% 12,9)$, emniyetli $(\% 7,3)$ ve huzurlu $(\% 7,3)$ kavramları öne çıkarken üçüncü sira tercihlerine göre ise emniyetli $(12,9)$, güvenilir $(\% 10,5)$, huzurlu $(\% 10,5)$ geleneksel $(\% 6,5)$ ve mutlu $(\% 6,5)$ kişilik özellikleri öne çıkmaktadır. Dördüncü sıra tercihlerinde güvenilir $(\% 9,7)$, emniyetli $(\% 8,9)$, küçük kent $(\% 8,9)$, geleneksel $(\% 6,5)$ ve dostça $(\% 6,5)$ kavramları ve son olarak beşinci sıra tercihlerinde ise huzurlu $(\% 19,4)$, güzel $(\% 12,1)$, küçük kent $(\% 10,5)$, güvenilir $(\% 9,7)$ ve sıcak $(\% 5,6)$ kişilik özellikleri dikkat çekmektedir. Özetle Artvin kentini en iyi anlatan kişilik özelliklerini aileyi yönelik, küçük kent, güvenilir, emniyetli, huzurlu, geleneksel, mutlu, dostça, güzel ve sıcak olarak ifade etmek mümkün gözükmektedir.

\subsubsection{Bayburt Marka Kent Kişiliğine Yönelik Tutumlar}

Katılımcılardan Bayburt'u en iyi anlatan beş kişilik özelliğini seçmeleri ve bunları önem sırasına göre sıralamaları istenmiştir.

\subsubsection{Artvin Marka Kent Kişiliğine Yönelik Tutumlar}

Artvin'de ikamet edenlere şehirlerinin kişiliğini en iyi anlatan beş özellik seçmeleri istenmiştir. Katılımcıların 55 kişilik özelliği içerisinden tercih ettikleri kişilik özelliklerine Tablo 7'de yer verilmektedir. Bu özelliklerin dişında katılımcıların da özellik ekleyebileceği diğer seçeneğinin de bulunduğu ölçekte elde edilen veriler şu şekildedir. 
Tablo 8. Bayburt Marka Kent Kișiliğine Yönelik Tutumlar

\begin{tabular}{|c|c|c|c|c|c|c|c|c|c|c|}
\hline & $\begin{array}{l}\text { Bİ } \\
\text { SII }\end{array}$ & $\begin{array}{l}\text { RINCI } \\
\text { RA }\end{array}$ & $\begin{array}{l}\text { İKI } \\
\text { SIR }\end{array}$ & $\begin{array}{l}\text { İNCI } \\
\mathbf{R A}\end{array}$ & & $\begin{array}{l}\text { ÜNC } \\
\text { IRA }\end{array}$ & $\begin{array}{l}\text { DÖ } \\
\text { NC } \\
\text { SIR }\end{array}$ & $\begin{array}{l}\text { RDÜ } \\
\ddot{U} \\
\mathbf{R A}\end{array}$ & $\begin{array}{l}\text { BE } \\
\text { I S }\end{array}$ & $\begin{array}{l}\text { şiNC } \\
\text { IRA }\end{array}$ \\
\hline & f & $\%$ & f & $\%$ & f & $\%$ & f & $\%$ & f & $\%$ \\
\hline $\begin{array}{l}\text { Aileye } \\
\text { Yönelik }\end{array}$ & 38 & 34,5 & 4 & 3,6 & 4 & 3,6 & 4 & 3,6 & 6 & 5,5 \\
\hline $\begin{array}{l}\text { Küęük } \\
\text { Kent }\end{array}$ & 40 & 36,4 & 23 & 20,9 & 7 & 6,4 & 5 & 4,5 & 1 &, 9 \\
\hline Geleneksel & 5 & 4,5 & 9 & 8,2 & 10 & 9,1 & 3 & 2,7 & 4 & 3,6 \\
\hline $\begin{array}{l}\text { Modası } \\
\text { Geçmiş }\end{array}$ & 1 & ,9 & 13 & 11,8 & 7 & 6,4 & 5 & 4,5 & & \\
\hline Mutlu & 1 & ,9 & 1 & ,9 & 6 & 5,5 & 5 & 4,5 & 1 &, 9 \\
\hline Emniyetli & 5 & 4,5 & 8 & 7,3 & 16 & 14,5 & 11 & 10,0 & 4 & 3,6 \\
\hline Güvenilir & 2 & 1,8 & 9 & 8,2 & 11 & 10,0 & 20 & 18,2 & 11 & 10,0 \\
\hline Özgüvenli & & & 1 & ,9 & 1 & ,9 & 8 & 7,3 & 3 & 2,7 \\
\hline Sağlam & & & & & 1 & ,9 & 1 & ,9 & 7 & 6,4 \\
\hline Saçma & 2 & 1,8 & 3 & 2,7 & & & 3 & 2,7 & 9 & 8,2 \\
\hline Huzurlu & 5 & 4,5 & 7 & 6,4 & 11 & 10,0 & 7 & 6,4 & 28 & 25,5 \\
\hline
\end{tabular}

Bayburt'ta ikamet edenlere göre, Bayburt şehrinin kişiliğini en iyi şekilde açıklayan özellikler sıralamasında birinci sıra tercihlerinde ön plana çıkan özellikler küçük kent $(\% 36,4)$, aileye yönelik $(\% 34,5)$, huzurlu $(\% 5,4)$, emniyetli $(\% 5,4)$ ve gelenekseldir $(\% 5,4)$. İkinci sıra tercihlerine göre küçük kent $(\% 20,9)$, modası geçmiş $(\% 11,8)$, geleneksel $(\% 8,2)$, güvenilir $(\% 8,2)$, emniyetli $(\% 7,3)$; üçüncü sıra tercihlerine göre emniyetli $(\% 14,5)$, güvenilir $(\% 10,0)$, huzurlu $(\% 10,0)$, geleneksel $(\% 9,1)$, küçük kent $(\% 6,4)$ ve modası geçmiş $(\% 6,4)$ kavramları dikkat çekmektedir. Dördüncü sıra tercihlerine göre ise güvenilir $(\% 18,2)$, emniyetli $(\% 10,0)$, özgüvenli $(\% 7,3)$, huzurlu $(\% 6,4)$, küçük kent $(\% 4,5)$, modası geçmiş $(\% 4,5)$, mutlu $(\% 4,5)$ özellikleri öne çıkarken beşinci sıra tercihlerine göre huzurlu $(\% 25,5)$, güvenilir $(\% 10,0)$, saçma $(\% 8,2)$, sağlam $(\% 6,4)$ ve aileye yönelik $(\% 5,5)$ özellikleri Bayburt'u en iyi anlatan kişilik özellikleri olarak görülmektedir.

\subsubsection{Giresun Marka Kent Kişiliğine Yönelik Tutumlar}

Giresunlulardan da kentlerinin marka kişiliğini en iyi anlatan beş özellik seçmeleri istenmiştir. Giresun'un marka kent kişilik özelliklerine yönelik tutumlar aşağıdaki tabloda yer almaktadır.

Tablo 9. Giresun Marka Kent Kişiliğine Yönelik Tutumlar

\begin{tabular}{|c|c|c|c|c|c|c|c|c|c|}
\hline & \multicolumn{2}{|c|}{$\begin{array}{l}\text { BİRINCI } \\
\text { SIRA }\end{array}$} & \multicolumn{2}{|c|}{$\begin{array}{l}\text { İKINCI } \\
\text { SIRA }\end{array}$} & \multicolumn{2}{|c|}{$\begin{array}{l}\text { ÜÇ己̈N } \\
\text { CÜ } \\
\text { SIRA }\end{array}$} & 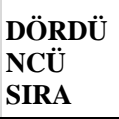 & \multicolumn{2}{|c|}{$\begin{array}{l}\text { BEŞiNCI } \\
\text { SIRA }\end{array}$} \\
\hline & f & $\%$ & f & $\%$ & f & $\%$ & f $\%$ & f & $\%$ \\
\hline $\begin{array}{l}\text { Aileye } \\
\text { Yönelik } \\
\end{array}$ & 33 & 19,6 & 7 & 4,2 & 1 & 6 & $2 \quad 1,2$ & & \\
\hline $\begin{array}{l}\text { Küçük } \\
\text { Kent }\end{array}$ & 39 & 23,2 & 22 & 13,1 & 9 & 5,4 & $6 \quad 3,6$ & 4 & 2,4 \\
\hline Geleneksel & 12 & 7,1 & 10 & 6,0 & 8 & 4,8 & $4 \quad 2,4$ & 4 & 2,4 \\
\hline Özgün & 3 & 1,8 & 9 & 5,4 & 4 & 2,4 & 21,2 & 3 & 1,8 \\
\hline Sicak & 2 & 1,2 & 6 & 3,6 & 11 & 6,5 & $7 \quad 4,2$ & 9 & 5,4 \\
\hline
\end{tabular}

\begin{tabular}{lllllllllll} 
Mutlu & 5 & 3,0 & $\mathbf{1 2}$ & $\mathbf{7 , 1}$ & 7 & 4,2 & 3 & 1,8 & $\mathbf{7}$ & $\mathbf{4 , 2}$ \\
\hline $\begin{array}{l}\text { Yaşam } \\
\text { Dolu }\end{array}$ & 2 & 1,2 & $\mathbf{9}$ & $\mathbf{5 , 4}$ & $\mathbf{8}$ & $\mathbf{4 , 8}$ & 5 & 3,0 & 6 & 3,6 \\
\hline Çalışkan & 2 & 1,2 & 1 &, 6 & $\mathbf{8}$ & $\mathbf{4 , 8}$ & $\mathbf{1 2}$ & $\mathbf{7 , 1}$ & 2 & 1,2 \\
\hline Emniyetli & 3 & 1,8 & 6 & 3,6 & 7 & 4,2 & $\mathbf{1 8}$ & $\mathbf{1 0 , 7}$ & 5 & 3,0 \\
\hline Güvenilir & 4 & 2,4 & $\mathbf{1 2}$ & $\mathbf{7 , 1}$ & $\mathbf{8}$ & $\mathbf{4 , 8}$ & $\mathbf{1 7}$ & $\mathbf{1 0 , 1}$ & $\mathbf{1 1}$ & $\mathbf{6 , 5}$ \\
\hline Güzel & $\mathbf{6}$ & $\mathbf{3 , 6}$ & 8 & 4,8 & 6 & 3,6 & $\mathbf{1 1}$ & $\mathbf{6 , 5}$ & $\mathbf{1 2}$ & $\mathbf{7 , 1}$ \\
\hline Gösterişli & & & & & 1 & 6 & 4 & 2,4 & $\mathbf{7}$ & $\mathbf{4 , 2}$ \\
\hline Huzurlu & $\mathbf{1 2}$ & $\mathbf{7 , 1}$ & 5 & 3,0 & 5 & 3,0 & $\mathbf{1 0}$ & $\mathbf{6 , 0}$ & $\mathbf{4 0}$ & $\mathbf{2 3 , 8}$
\end{tabular}

Araştırmaya katılan deneklerin ilk tercihlerine göre Giresun'un marka kent kişiliği küçük kent $(\% 23,2)$, aileye yönelik $(\% 19,6)$, geleneksel $(7,1)$, huzurlu $(\% 7,1)$ ve güzel $(\% 3,6)$ olarak ifade edilmektedir. İkinci sira tercihlerine göre Giresun; küçük kent $(\% 13,1)$, mutlu $(\% 7,1)$, güvenilir $(\% 7,1)$, geleneksel $(\% 5,4)$ ve yaşam dolu $(\% 5,4)$; üçüncü sıra tercihlerine göre ise sıcak $(\% 6,5)$, küçük kent $(\% 5,4)$, geleneksel $(\% 4,8)$, güvenilir $(\% 4,8)$, çalışkan $(\% 4,8)$, yaşam dolu $(\% 4,8)$ bir kent olarak tanımlanmaktadır. Dördüncü sıra tercihlerine göre emniyetli $(\% 10,7)$, güvenilir $(\% 10,1)$, çalışkan $(\% 7,1)$, güzel $(\% 6,5)$ ve huzurlu $(\% 6,0)$ olarak görülen Giresun; beşinci sıra tercihlerine göre ise huzurlu $(\% 23,8)$, güzel $(\% 7,1)$, güvenilir $(\% 6,5)$, sicak $(\% 5,4)$, mutlu $(\% 4,2)$ ve gösterişli $(\% 4,2)$ bir kent olarak ifade edilmektedir.

\subsubsection{Gümüşhane Marka Kent Kişiliğine Yönelik Tutumlar}

Araştırmaya katılan Gümüşhaneliler, kentlerinin marka kişiliğini en iyi anlatan beş özelliği aşağıda tablodaki şekilde ifade etmişlerdir.

Tablo 10. Gümüşhane Marka Kent Kişiliğine Yönelik Tutumlar

\begin{tabular}{|c|c|c|c|c|c|c|c|c|c|c|}
\hline & \multicolumn{2}{|c|}{$\begin{array}{l}\text { BİRINCI } \\
\text { SIRA }\end{array}$} & \multicolumn{2}{|c|}{$\begin{array}{l}\text { İKINCİ } \\
\text { SIRA }\end{array}$} & \multicolumn{2}{|c|}{$\begin{array}{l}\text { ÜÇÜNC } \\
\text { Ü SIRA }\end{array}$} & \multicolumn{2}{|c|}{$\begin{array}{l}\text { DÖRDÜ } \\
\text { NCÜ } \\
\text { SIRA }\end{array}$} & \multicolumn{2}{|c|}{$\begin{array}{l}\text { BESSIINC } \\
\text { İ SIRA }\end{array}$} \\
\hline & f & $\%$ & f & $\%$ & f & $\%$ & f & $\%$ & f & $\%$ \\
\hline $\begin{array}{l}\text { Aileye } \\
\text { Yönelik }\end{array}$ & 29 & 22,5 & 11 & 8,5 & 15 & 11,6 & 7 & 5,4 & 8 & 6,2 \\
\hline $\begin{array}{l}\text { Küçüik } \\
\text { Kent }\end{array}$ & 42 & 32,6 & 25 & 19,4 & 6 & 4,7 & 7 & 5,4 & 4 & 3,1 \\
\hline Geleneksel & 5 & 3,9 & 15 & 11,6 & 13 & 10,1 & 8 & 6,2 & 7 & 5,4 \\
\hline Dostça & 2 & 1,6 & 5 & 3,9 & 9 & $\mathbf{7 , 0}$ & 8 & 6,2 & 7 & 5,4 \\
\hline Sicak & 1 &, 8 & 4 & 3,1 & 7 & 5,4 & 5 & 3,9 & 8 & 6,2 \\
\hline Emniyetli & 9 & 7,0 & 15 & 11,6 & 17 & 13,2 & 13 & 10,1 & 6 & 4,7 \\
\hline Güvenilir & 15 & 11,6 & 14 & 10,9 & 13 & 10,1 & 22 & 17,1 & 4 & 3,1 \\
\hline Huzurlu & 7 & 5,4 & 5 & 3,9 & 9 & $\mathbf{7 , 0}$ & 11 & 8,5 & 20 & 15,5 \\
\hline
\end{tabular}

Gümüşhane'de araştırmaya katılan deneklerin birinci tercihlerine göre şehrin marka kişiliği; küçük kent $(\% 32,6)$, aileye yönelik $(\% 22,5)$, güvenilir $(\% 11,6)$, emniyetli $(\% 7,0)$ ve huzurlu $(\% 5,4)$ olarak tanımlanmaktadır. İkinci sıra tercihlerine göre yine küçük kent $(\% 19,4)$, geleneksel $(\% 11,6)$, emniyetli $(\% 11,6)$, güvenilir $(\% 10,9)$ ve aileye yönelik $(\% 8,5)$ olarak görülürken, üçüncü sıra tercihlerinde ise Gümüşhane; emniyetli $(\% 13,2)$ aileye yönelik $(\% 11,6)$, geleneksel $(\% 10,1)$, güvenilir $(\% 10,1)$, dostça $(\% 7,0)$ ve 
huzurlu $(\% 7,0)$ bir kent olarak görülmektedir. Dördüncü sıra tercihlerinde güvenilir $(\% 17,1)$, emniyetli $(\% 10,1)$, huzurlu $(\% 8,5)$, dostça $(\% 6,2)$ ve geleneksel $(\% 6,2)$ bir kent olarak algılanırken, beşinci sıra tercihlerinde huzurlu $(\% 15,5)$, aileye yönelik $(\% 6,2)$, sicak $(\% 6,2)$, geleneksel $(\% 5,4)$ ve dostça $(\% 5,4)$ bir şehir olarak ifade edilmektedir.

\subsubsection{Ordu Marka Kent Kişiliğine Yönelik Tutumlar}

Ordu'da ikamet edenler kentlerinin marka kişiliğini aşağıda yer alan tablodaki özelliklerle tanımlamaktadırlar.

Tablo 11. Ordu Marka Kent Kişiliğine Yönelik Tutumlar

\begin{tabular}{|c|c|c|c|c|c|c|c|c|c|c|}
\hline & \multicolumn{2}{|c|}{$\begin{array}{l}\text { BİRINCI } \\
\text { SIRA }\end{array}$} & \multicolumn{2}{|c|}{$\begin{array}{l}\text { İKİNC } \\
\text { İ SIRA }\end{array}$} & \multicolumn{2}{|c|}{$\begin{array}{l}\text { ÜÇÜNC } \\
\text { Ü SIRA }\end{array}$} & \multicolumn{2}{|c|}{$\begin{array}{l}\text { DÖRD } \\
\text { ÜNCÜ } \\
\text { SIRA }\end{array}$} & \multicolumn{2}{|c|}{$\begin{array}{l}\text { BEŞINC } \\
\text { I SIRA }\end{array}$} \\
\hline & $\mathbf{f}$ & $\%$ & $\mathbf{f}$ & $\%$ & f & $\%$ & f & $\%$ & f & $\%$ \\
\hline $\begin{array}{l}\text { Aileye } \\
\text { Yönelik }\end{array}$ & 74 & 30,8 & 15 & 6,3 & 5 & 2,1 & 5 & 2,1 & 10 & 4,2 \\
\hline $\begin{array}{l}\text { Küçük } \\
\text { Kent }\end{array}$ & 22 & 9,2 & 12 & 5,0 & 10 & 4,2 & 8 & 3,3 & 12 & 5,0 \\
\hline Geleneksel & 15 & 6,3 & 19 & 7,9 & 9 & 2,8 & 5 & 2,1 & 11 & 4,6 \\
\hline Mutlu & 8 & 3,3 & 11 & 4,6 & 17 & 7,1 & 8 & 3,3 & 8 & 3,3 \\
\hline $\begin{array}{l}\text { Yaşam } \\
\text { Dolu }\end{array}$ & 7 & 2,9 & 14 & 5,8 & 14 & 5,8 & 7 & 2,9 & 4 & 1,7 \\
\hline Eğlenceli & 3 & 1,3 & 6 & 2,5 & 15 & 6,3 & 10 & 4,2 & 6 & 2,5 \\
\hline Emniyetli & 11 & 4,6 & 13 & 5,4 & 11 & 4,6 & 23 & 9,6 & 7 & 2,9 \\
\hline Güvenilir & 7 & 2,9 & 16 & 6,7 & 10 & 4,2 & 13 & 5,4 & 6 & 2,5 \\
\hline Özgüvenli & 2 &, 8 & 3 & 1,3 & 5 & 2,1 & 2 &, 8 & 11 & 4,6 \\
\hline Güzel & 6 & 2,5 & 12 & 5,0 & 8 & 3,3 & 20 & 8,3 & 22 & 9,2 \\
\hline Gösterişli & & & 7 & 2,9 & 6 & 2,5 & 8 & 3,3 & 12 & 5,0 \\
\hline Huzurlu & 16 & 6,7 & 5 & 2,1 & 15 & 6,3 & 14 & 5,8 & 30 & 12,5 \\
\hline
\end{tabular}

Yukarıdaki tabloda yer alan veriler incelendiğinde araştırmaya katılan deneklerin ilk tercihlerine göre Ordu'nun kişiliği aileye yönelik $(\% 30,8)$, küçük kent $(\% 9,2)$, huzurlu $(\% 6,7)$ geleneksel $(\% 6,3)$ ve emniyetli $(\% 4,6)$ olarak ifade edilmektedir. İkinci sıra tercihlerine göre Ordu; geleneksel $(\% 7,9)$, güvenilir $(\% 6,7)$, aileye yönelik $(\% 6,3)$, yaşam dolu $(\% 5,8)$ ve emniyetli $(\% 5,4)$ bir kent olarak değerlendirilmektedir. Üçüncü sıra tercihlerine göre ise mutlu $(\% 7,1)$, eğlenceli $(\% 6,3)$, huzurlu $(\% 6,3)$, yaşam dolu $(\% 5,8)$ ve emniyetli $(\% 4,6)$ bir kent olarak tanımlanmaktadır. Dördüncü sıra tercihlerine göre emniyetli $(\% 9,6)$, güzel $(\% 8,3)$, huzurlu $(\% 5,8)$, güvenilir $(\% 5,4)$ ve eğlenceli $(\% 4,2)$ olarak görülen Ordu, beşinci sıra tercihlerine göre ise huzurlu $(\% 12,5)$, güzel $(\% 9,2)$, gösterişli $(\% 5,0)$, küçük kent $(\% 5,0)$, geleneksel $(\% 4,6)$ ve özgüvenli $(\% 4,6)$ olarak ifade edilmektedir.

\subsubsection{Rize Marka Kent Kişiliğine Yönelik Tutumlar}

Araştırmanın gerçekleştirildiği diğer illerde olduğu gibi Rize'de de katılımcılardan şehirlerinin marka kişiliğini en iyi anlatan beş özellik seçmeleri istenmiştir. Katılımcıların 55 kişilik özelliği içerisinden tercih ettiklerin kişilik özelliklerine Tablo 12'de yer verilmektedir. Bu özelliklerin dışında katılımcıların da özellik ekleyebileceği diğer seçeneğinin de bulunduğu ölçekte elde edilen veriler şu şekildedir.
Tablo 12. Rize Marka Kent Kişiliğine Yönelik Tutumlar

\begin{tabular}{|c|c|c|c|c|c|c|c|c|c|c|}
\hline & \multicolumn{2}{|c|}{$\begin{array}{l}\text { BİRINCI } \\
\text { SIRA }\end{array}$} & \multicolumn{2}{|c|}{$\begin{array}{l}\text { İKINCİ } \\
\text { SIRA }\end{array}$} & \multicolumn{2}{|c|}{$\begin{array}{l}\text { ÜÇÜN } \\
\text { CÜ } \\
\text { SIRA }\end{array}$} & \multicolumn{2}{|c|}{$\begin{array}{l}\text { DÖRDÜ } \\
\text { NCÜ } \\
\text { SIRA }\end{array}$} & \multicolumn{2}{|c|}{$\begin{array}{l}\text { BEŞINCC } \\
\text { İ SIRA }\end{array}$} \\
\hline & $\mathbf{f}$ & $\%$ & $\mathbf{f}$ & $\%$ & $\mathbf{f}$ & $\%$ & f & $\%$ & $\mathbf{f}$ & $\%$ \\
\hline $\begin{array}{l}\text { Aileye } \\
\text { Yönelik }\end{array}$ & 42 & 23,7 & 5 & 2,8 & 4 & 2,3 & 5 & 2,8 & 5 & 2,8 \\
\hline $\begin{array}{l}\text { Küçük } \\
\text { Kent }\end{array}$ & 32 & 18,1 & 20 & 11,3 & 1 & ,6 & 3 & 1,7 & 2 & 1,1 \\
\hline Geleneksel & 18 & 10,2 & 18 & 10,2 & 13 & 7,3 & 1 & ,6 & 1 & 6 \\
\hline Açık Sözlü & 18 & 10,2 & 12 & 6,8 & 8 & 4,5 & 2 & 1,1 & 3 & 1,7 \\
\hline Özgün & 5 & 2,8 & 10 & 5,6 & 1 & ,6 & 2 & 1,1 & 2 & 1,1 \\
\hline Dostça & 2 & 1,1 & 10 & 5,6 & 9 & 5,1 & 2 & 1,1 & 4 & 2,3 \\
\hline Sicak & 5 & 2,8 & 8 & 4,5 & 15 & 8,5 & 8 & 4,5 & 2 & 1,1 \\
\hline Maceracı & 4 & 2,3 & 9 & 5,1 & 11 & 6,2 & 6 & 3,4 & 3 & 1,7 \\
\hline Şakacı & 9 & 5,1 & 6 & 3,4 & 11 & 6,2 & 14 & 7,9 & 3 & 1,7 \\
\hline Eğlenceli & 4 & 2,3 & 6 & 3,4 & 9 & 5,1 & 4 & 2,3 & 3 & 1,7 \\
\hline Çalışkan & & & 6 & 3,4 & 7 & 4,0 & 15 & 8,5 & 9 & 5,1 \\
\hline Güvenilir & 6 & 3,4 & 2 & 1,1 & 9 & 5,1 & 20 & 11,3 & 9 & 5,1 \\
\hline Özgüvenli & & & 4 & 2,3 & 2 & 1,1 & 3 & 1,7 & 11 & 6,2 \\
\hline Etkileyici & & & & & 1 & ,6 & 8 & 4,5 & 6 & 3,4 \\
\hline Güzel & 2 & 1,1 & & & 3 & 1,7 & 8 & 4,5 & 13 & 7,3 \\
\hline Güçlü & 1 & ,6 & & & 2 & 1,1 & 2 & 1,1 & 11 & 6,2 \\
\hline Huzurlu & 1 & ,6 & 2 & 1,1 & 2 & 1,1 & 6 & 3,4 & 18 & 10,3 \\
\hline
\end{tabular}

Araştırmaya katılan deneklerin ilk tercihlerine göre Rize'nin marka kent kişiliği aileye yönelik $(\% 23,7)$, küçük kent $(\% 18,1)$, geleneksel $(\% 10,2)$, açık sözlü $(10,2)$ ve şakacı $(\% 5,1)$ olarak ifade edilmektedir. İkinci sıra tercihlerine göre ise Rize; küçük kent $(\% 11,3)$, geleneksel $(\% 10,2)$, açık sözlü $(\% 6,8)$, özgün $(\% 5,6)$ ve dostça $(\% 5,6)$ olarak tanımlanmaktadır. Üçüncü sıra tercihlerine göre ise sıcak $(\% 8,5)$, geleneksel $(\% 7,3)$, maceracı $(\% 6,2)$, şakacı $(\% 6,2)$, eğlenceli $(\% 5,1)$, güvenilir $(\% 5,1)$ ve dostça $(\% 5,1)$ dördüncü sıra tercihlerine göre güvenilir $(\% 11,3)$, çalışkan $(\% 8,5)$, şakacı $(\% 7,9)$, sicak $(\% 4,5)$, güzel $(\% 4,5)$ ve etkileyici $(\% 4,5)$ bir kent olarak değerlendirilmektedir. Beşinci sıra tercihlerine göre ise Rize, huzurlu (\%10,3), güzel $(\% 7,3)$, özgüvenli $(\% 6,2)$, güçlü $(\% 6,2)$, çalışkan $(\% 5,1)$ ve güvenilir $(\% 5,1)$ bir kent olarak ifade edilmektedir.

\subsubsection{Trabzon Marka Kent Kişiliğine Yönelik Tutumlar}

Trabzon ikamet edenler içesinden araştırmaya katılanlardan şehirlerinin marka kişiliğini en iyi anlatan beş özelliği seçmeleri istenmiştir. Katılımcıların 55 kişilik özelliği içerisinden tercih ettikleri kişilik özelliklerine Tablo 13'de yer verilmektedir. Bu özelliklerin dışında katılımcıların da özellik ekleyebileceği diğer seçeneğinin de bulunduğu ölçekte elde edilen veriler şu şekildedir. 
Tablo 13. Trabzon Marka Kent Kişiliğine Yönelik Tutumlar

\begin{tabular}{|c|c|c|c|c|c|c|c|c|c|c|}
\hline & \multicolumn{2}{|c|}{$\begin{array}{l}\text { BIRINACI } \\
\text { SIRA }\end{array}$} & \multicolumn{2}{|c|}{$\begin{array}{l}\text { İKİNCI } \\
\text { SIRA }\end{array}$} & \multicolumn{2}{|c|}{$\begin{array}{l}\text { ÜÇÜNC } \\
\text { Ü SIRA }\end{array}$} & \multicolumn{2}{|c|}{ 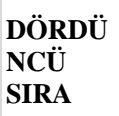 } & \multicolumn{2}{|c|}{$\begin{array}{l}\text { BEŞİNC } \\
\text { I SIRA }\end{array}$} \\
\hline & f & $\%$ & f & $\%$ & f & $\%$ & f & $\%$ & $\mathbf{f}$ & $\%$ \\
\hline $\begin{array}{l}\text { Aileye } \\
\text { Yönelik } \\
\end{array}$ & 57 & 20,9 & 15 & 5,5 & 3 & 1,1 & 13 & 4,8 & 10 & 3,7 \\
\hline $\begin{array}{l}\text { Küçük } \\
\text { Kent }\end{array}$ & 26 & 9,5 & 13 & 4,8 & 8 & 2,9 & 5 & 1,8 & 6 & 2,2 \\
\hline
\end{tabular}

$\begin{array}{lllllllllll}\text { Geleneksel } & 41 & \mathbf{1 5 , 0} & \mathbf{2 7} & \mathbf{9 , 9} & \mathbf{1 9} & \mathbf{7 , 0} & 8 & 2,9 & 7 & 2,6\end{array}$

\begin{tabular}{lllllllllll}
\hline Açık Sözlü & $\mathbf{1 3}$ & $\mathbf{4 , 8}$ & $\mathbf{1 7}$ & $\mathbf{6 , 2}$ & $\mathbf{1 7}$ & $\mathbf{6 , 2}$ & 8 & 2,9 & 8 & 2,9
\end{tabular}

\begin{tabular}{lllllllllll}
\hline Dostça & 4 & 1,5 & 11 & 4,0 & 8 & 2,9 & $\mathbf{1 2}$ & $\mathbf{4 , 4}$ & 2 &, 7 \\
\hline Sicak & 12 & 4,4 & 6 & 2,2 & 12 & 4,4 & $\mathbf{1 6}$ & $\mathbf{5 , 9}$ & 12 & 4,4
\end{tabular}

\begin{tabular}{lllllllllll}
\hline Maceracı & 1 & 4 & 1 &, 4 & 5 & 1,8 & $\mathbf{1 2}$ & $\mathbf{4 , 4}$ & 1 &, 4
\end{tabular}

$\begin{array}{lllllllllll}\text { Şakacı } & 2 & , 7 & 10 & 3,7 & \mathbf{1 6} & \mathbf{5 , 9} & \mathbf{1 2} & \mathbf{4 , 4} & 8 & 2,\end{array}$

\begin{tabular}{llllllllllll}
\hline Güvenilir & $\mathbf{1 4}$ & $\mathbf{5 , 1}$ & 12 & 4,4 & $\mathbf{1 5}$ & $\mathbf{5 , 5}$ & $\mathbf{2 6}$ & $\mathbf{9 , 5}$ & $\mathbf{1 5}$ & $\mathbf{5 , 5}$
\end{tabular}

$\begin{array}{lllllllllll}\text { Özgüvenli } & 3 & 1,1 & 5 & 1,8 & 10 & 3,7 & 6 & 2,2 & \mathbf{1 3} & \mathbf{4 , 8}\end{array}$

\begin{tabular}{lcccccccccc}
\hline Güzel & 6 & 2,2 & 9 & 3,3 & 8 & 2,9 & $\mathbf{1 5}$ & $\mathbf{5 , 5}$ & $\mathbf{1 4}$ & $\mathbf{5 , 1}$ \\
\hline Güçlü & 5 & 1,8 & 3 & 1,1 & 5 & 1,8 & 10 & 3,7 & $\mathbf{1 5}$ & $\mathbf{5 , 5}$ \\
\hline Saçma & 2 &, 7 & 1 &, 4 & & & 5 & 1,8 & $\mathbf{1 3}$ & $\mathbf{4 , 8}$ \\
\hline Huzurlu & 7 & 2,6 & 6 & 2,2 & $\mathbf{1 3}$ & $\mathbf{4 , 8}$ & 4 & 1,5 & $\mathbf{2 7}$ & $\mathbf{9 , 9}$
\end{tabular}

Araştırmaya katılan deneklerin birinci tercihlerine göre Trabzon aileye yönelik $(\% 20,9)$, geleneksel $(\% 15,0)$, küçük kent $(\% 9,5)$, güvenilir $(\% 5,1)$ ve açık sözlü $(\% 4,8)$ olarak değerlendirilmektedir. İkinci sıra tercihlerine göre geleneksel $(\% 9,9)$, açık sözlü $(\% 6,1)$, aileye yönelik $(\% 5,5)$, emniyetli $(\% 5,5)$ ve güvenilir $(\% 4,4)$ olarak görülen Trabzon, üçüncü sıra tercihlerine göre ise geleneksel $(\% 7,0)$, açık sözlü $(\% 6,2)$, şakacı $(\% 5,9)$, güvenilir $(\% 5,5)$ ve huzurlu $(\% 4,8)$ olarak algılanmaktadır. Dördüncü sira tercihlerine göre ele alındığında güvenilir $(\% 9,5)$, sıcak $(\% 5,9)$, güzel $(\% 5,5)$, aileye yönelik $(\% 4,8)$ dostça $(\% 4,4)$, macerac1 $(\% 4,4)$ ve şakacı $(\% 4,4)$ bir şehir olarak değerlendirilen Trabzon beşinci sıra tercihlerine göre ise huzurlu $(\% 9,9)$, güçlü $(\% 5,5)$, güzel $(\% 5,1)$ özgüvenli $(\% 4,8)$ ve saçma $(\% 4,8)$ kavramlarıyla ifade edilmiştir.

$\mathrm{Bu}$ veriler 1şığında Trabzon'un Trabzonlular tarafindan geleneksel, aileye yönelik, küçük kent, güvenilir, açık sözlü, emniyetli, şakacı, huzurlu, sıcak, güzel, özgüvenli ve saçma bir şehir olarak görüldügüü söylenebilir.

\subsubsection{Marka Kent Kişilik Tutumlarının Fark Testi Sonuçları}

$\mathrm{Bu}$ araştırmada örneklem olarak alınan kentlerin kişilikleri ile ilgili katılımcıların tutumlarının, onların ikamet ettikleri yere, yaşlarına, cinsiyetlerine, eğitim durumlarına, medeni durumlarına ve gelir durumlarına göre bir farklılık gösterip göstermediğini ortaya koymak amaciyla t-testi ve tek yönlü varyans analizi testi gerçekleştirilmiştir.

Katılımcıların şehirlerin marka kişiliğine verdikleri cevapların ikamet edilen şehre göre değişip değişmediğini analiz etmek amaciyla one way anova analizi gerçekleştirilmiştir. Buna göre birinci sıra marka kişiliği tercihlerinin $(\mathrm{df}=1217 ; \mathrm{f}=4,860 ; \mathrm{p}=, 000)$ ikamet edilen şehirlere göre anlamlı farklılık gösterdiği görülmektedir. $\mathrm{Bu}$ farklılığın ise özellikle Artvin ile Bayburt $(p=, 002)$ ve Rize $(\mathrm{p}=, 026)$; Bayburt ile Giresun $(\mathrm{p}=, 015)$, Ordu $(\mathrm{p}=, 002)$, ve Trabzon $(p=, 003)$; Ordu ile Rize $(p=, 027)$ ve Rize ile Trabzon $(\mathrm{p}=, 040)$ arasında ortaya çıktığı anlaşılmaktadır. İkinci sira tercihlerine verilen cevapların da ikamet edilen şehre göre farklılık (df=1217; $\mathrm{f}=5,694 ; \mathrm{p}=, 000)$ gösterdiği bu çalışmada, farklılığın Artvin ile Rize $(p=, 031)$, Bayburt ile Ordu ( $\mathrm{p}=, 048)$; Gümüşhane ile Ordu $(\mathrm{p}=, 003)$; Ordu ile Rize $(p=, 000)$ ve Rize ile Trabzon $(p=, 005)$ arasında olduğu anlaşılmaktadır. Üçüncü sıra tercihleri açısından da anlamlı farklılık $\quad(\mathrm{df}=1217 ; \mathrm{f}=3,456 ; \quad \mathrm{p}=, 002)$ bulunmaktadır. Farklılığın olduğu iller ise şu şekildedir; Gümüşhane ile Ordu $(p=, 001)$ ve Trabzon $(p=, 040)$. Dördüncü sira tercihlerinde de anlamlı farklılığın $(\mathrm{df}=1215 ; \mathrm{f}=2,928$; $\mathrm{p}=$,008) gözlemlendiği bu araştırmada Gümüşhane ile Rize arasında farklılaşma $(\mathrm{p}=, 037)$ söz konusu iken; Beşinci sıra tercihlerinde de anlamlı bir farklılık söz konusudur $(d f=1194 ; f=4,807 ; p=, 000)$. Söz konusu farklılık ise Artvin ile Rize ( $p=, 036)$; Bayburt ile Gümüşhane $(p=, 006)$; Giresun ile Gümüşhane $(p=, 008)$ ve Gümüşhane ile Rize $(p=, 000)$ arasındadır.

\section{Sonuç}

Ticaret savaşlarının yoğun bir şekilde yaşandığı günümüzde hem işletmeler hem de şehirler ve devletler, bu savaşlardan galip çıkabilmek için markalaşma çalışmalarına önem vermektedir. Kendilerini farklılaştırmak ve tüketici gözünde değerli hale getirmek böylece ticaret savaşlarında stratejik üstünlüğü elde etmeyi arzulayan işletmelerin, şehirlerin ve devletlerin sahip olmak istedikleri marka olgusu, birçok değişkenden oluşmaktadır. $\mathrm{Bu}$ değişkenlerden biri de kişiliktir.

Teknoloji ile birlikte yalnızlaşan insan için bir dost ve bir sırdaş olan marka, ürün, hizmet veya bir şehrin sunamadığı duyguları sunarak bir kişilik kazanmaktadır. Yeri geldiğinde mutlu ve sevecen, yeri geldiğinde agresif ve güçlü, yeri geldiğinde karizmatik veya aşk dolu olabilme gibi potansiyellere sahip olan markalar, kazandıkları bu kişilik özellikleriyle tüketicilerin gönlünde taht kurabilmektedirler. Böylece marka olarak ifade edilen o soyut değer, kaybedildiğinde kişilere hüzün verebilmekte, kazanıldığında mutluluk kaynağına dönüşebilmektedirler. Ürün veya hizmetler gibi şehirlerde markalaşmadan önce dünyada var olan milyonlarca kilometre kare toprağın sıradan parçası hükmünde iken markalaşınca bir kişiliği olan tarifsiz bir soyut değer halini almaktadır.

Özellikle Doğu Karadeniz şehirlerinin marka kişilikleri üzerine odaklanan bu çalışma, alışıla gelmiş çalışmalardan farklı olarak dış paydaşların değil iç paydaşların tutumlarına odaklanmaktadır. Çünkü markalaşmak öncelikle iç dinamiklerden başlamaktadır. Kendi içinde markalaşma algısını oluşturamamış bir mekanizmanın dışarıda da markalaşması mümkün değildir. Bu gerçeklerden hareketle bu çalışmada örneklem olarak alınan şehirlerde yaşayan kent sakinlerinin kendi şehirlerinin marka kişiliğine yönelik tutumları ölçülmeye çalışılmıştır. Elde edilen sonuçlara göre, örnekleme konu olan şehirlerin farklı büyüklükte olmasına rağmen, tüm şehirlerde ön plana çıkan kişilik özelliklerinden birinin, küçük şehir kişilik özelliği olduğu görülmektedir. Trabzon ve Ordu gibi şehirlerde yaşayan şehir sakinlerinin kendi şehirlerinin kişilik özellikleri arasında küçük şehir 
kavramına yer vermeleri, bu iki şehir için en önemli problemlerden biri olarak görülmektedir.

Kişilik özellikleri incelendiğinde bu şehirlerin ortak kişilik özelliklerinin aileye yönelik, küçük kent, geleneksel, emniyetli, güvenilir, huzurlu olarak tanımlandığı anlaşılmaktadır. Bunun yanında genel olarak olumlu kişilik özellikleriyle tanımlanan bu şehirler için belki de en büyük problem, bu şehirlerin özgün kişilik özelliklerine sahip olmamalarıdır. Daha açık bir ifadeyle bölgenin en büyük şehri olan ve bir anlamda bölgenin kalbi durumunda olan Trabzon'un kişilik özellikleriyle Ordu'nun, Rize'nin, Artvin'in hatta Gümüşhane'nin kişilik özelliklerinin benzer olmaması gerekir. Yine aynı şekilde nispeten daha butik özelliklere sahip olan Gümüşhane'nin de Bayburt, Artvin (her ne kadar coğrafik açıdan çok benzer olsalar da), Trabzon, Ordu, Rize ve Giresun ile veya Türkiye ve dünyadaki herhangi bir şehir ile benzer kişilik özelliklerine sahip olmaması gerekir. Çünkü bu, markalaşmanın temel kriterlerinden biri olan özgünlük ya da farklı olma durumuna aykırıdır. Gerçek anlamda marka olmak isteyen bir şehrin her şeyden önce özgün bir marka vaadine ve bu vaade uygun bir marka kişiliğine sahip olması gerekmektedir.

Bu çalışma çerçevesinde örneklem olarak ele alınan şehirler için marka kişiliği önerisinde bulunulması yerinde olacaktır. $\mathrm{Bu}$ araştırmanın yazarları tarafından; Trabzon için "spor şehri" vaadi çerçevesinde sportif, canlı, dinamik, azimli ve hırslı kişilik özelliklerinin; Rize için "yaratıcılık başkenti" çerçevesinde (ki bu Rize'yi ve Rizelileri ayıran en önemli özelliktir (bkz. mimari uygulamalar); yaratıcı, özgün, şaşırtıcı, beklenmedik kişilik özelliklerinin uygun olacağı önerilmektedir. Bunun yanında yine örneklem içerisinde yer alan Ordu için; "oksijenin yurdu" (O2) (mevcut slogan), Gümüşhane ve Artvin için "adrenalin şehri" ana vaadi çerçevesinde; çılgın, heyecan verici, coşkulu kişilik özelliklerinin; Giresun için ise findıklarıyla ünlü olmasından dolayı; "enerji şehri” kişilik özelliklerinin ve Bayburt için ise Dedekorkut'tan dolayı "Türk Masalları Şehri” vaadi çerçevesinde milli, tarihi, kadim gelenek, Türk kültürü, masalsı kişilik özelliklerinin kullanılması gerektiği önerisi getirilmektedir.

İç paydaşlar üzerinde uygulanan bu çalışmanın dış paydaşlar üzerinde de uygulanması, bu şehirlerin markalaşma çalışmalarına önemli katkı sunacaktır.

\section{Kaynakça}

Aaker, J. L. (1997). Dimensions of Brand personality. Journal of Marketing Research, 34(3), 347-356.

Aaker, D. A., \& Joachimsthaler, E. (2000). The brand relationship spectrum: The key to the brand architecture challenge. California management review, 42(4), 823.Aaker, J. L. (1997). Dimensions of Brand personality, Jmr Journal of Marketing Research, 34, 3, ab1/inform Global, S.347-356.

Aksoy, A. (2005). Yeni Reklamcllı, İstanbul Bilgi Üniversitesi Yayınları, İstanbul.

Aslan, E. Ş. (2014). Marka 2.0 stratejileri bağlamında global markaların sosyal medyada gündem belirlemesi: Markaların 2.0 gündemi, yayınlanmamış doktora tezi, Gazi Üniversitesi Sosyal Bilimler Enstitüsü, Halkla İlişkiler ve Tanıtım Anabilim Dalı, Ankara.
Borça, G. (2007). Bu topraklardan Dünya markası çıkar $m \imath$ ?, 9. basım, Mediacat, İstanbul.

Bruce, D. \& Harvey, D. (2010). Marka bilmecesi, çev: Aslı Özer, Türkiye İş Bankası Kültür yayınları, İstanbul.

Buckıngham, I. P. (2011). Brand champions, Palgrave Macmillan, New York.

Elden, M. (2009). Reklam ve Reklamcılık, Say yayınları, İstanbul.

Erdil, T. S., \& Uzun, Y. (2009). Marka olmak. Beta basım yayım dağıtım, İstanbul.

Geuens, M., Weijters, B., \& De Wulf, K. (2009). A new measure of Brand personality. International Journal of Research in Marketing, 26(2), 97-107.

Grant, J. (2006). Markaların Inovasyon manifestosu, çev: Aytül Özer, Mediacat, İstanbul.

Henry, S. (2001). Yaratıcı iş özeti sunumu: Yaratıcı bakış açısı, derleyen: Leslie Butterfield, Reklamda mükemmele ulaşmak (Íçinden), çev: Muharrem Ayın vd., Reklamcılık Vakfı yayınları, İstanbul, S. 167-180.

İlgüner, M. \& Asplund, C. (2011). Marka Şehir, birinci basım, Markating, İstanbul.

Keller, K. L. (2008). Strategic Brand management: Building, measuring and managing Brand equity, third edition, Pearson Education, Inc, New Jersey.

Kırdar, Y. (2003). Marka stratejilerinin oluşturulması; CocaCola örneği, Review of Social, Economic \& Business Studies, Vol.3/4, S.233-250.

Koç, E. (2011). Tüketici davranışı ve pazarlama stratejileri: Global ve yerel yaklaşım, 3. baskı, Seçkin yayıncılık, Ankara.

Moon, M. \& Millison D. (2003). Ateşten markalar-Internet çağında marka sadakati yaratmanın yolları, çev: Ş. Tanju Kalkay, Mediacat, İstanbul.

Morgan, A. (2001). Büyük balığı yutmak-Meydan okuyan markaların lider markalarla rekabet etme yolları, çev: Muhsin Karaş, Mediacat, Ankara.

Pile, T. (2001). Toplam iletişim stratejisi, derleyen: Leslie Butterfield, Reklamda mükemmele ulaşmak (içinden), çev: Muharrem Ayın vd., Reklamcılık Vakfı yayınları, İstanbul, S. 239-251.

Pringle, H. \& Thompson M. (2000). Marka ruhu, çev: Zeynep Yelçe ve Canan Feyyat, Scala yayıncılık, İstanbul.

Sullivan, L. (2004). Satan Reklam yaratmak, çev: Sevtap Yaman, ikinci bask1, Mediacat, İstanbul.

Taşkın, Ç. \& Akat, Ö. (2008). Marka ve marka stratejileri, Alfa Aktuiel yayınları, Bursa.

Tosun, N. B. (2010). Illetişim temelli marka yönetimi, Beta basım, İstanbul.

Urry, J. (2009). Turist bakışı, çev: Enis Tataroğlu-İbrahim Yıldız, Bilgesu yayıncılık, Ankara.

Ustakara, F. \& Aydemir, M. (2016). Spor kulüpleri ve marka: İletişim fakültesi öğrencileri örneğinde bir araştırma. Journal of Yaşar University, 11(41), 16-29.

Uztuğ, F. (2003). Markan kadar konuş! Marka iletişimi stratejileri, ikinci baskı, Mediacat, İstanbul. 


\section{Extended Abstract}

\section{Subject of the research}

Personality traits are peculiar to humans. In addition, as a result of the fact that these characteristics can be transferred to objects, personality traits can be attributed to products, services or destinations. This situation, which emerges with the formation of more emotional bonds, manifests itself clearly in brands with intangible values and strong emotional aspects. Having personality traits, which is one of the basic elements of being a brand, is mostly the result of a spontaneous, uncontrolled and unconscious process. However, one of the first steps for a destination that wants to brand is to have a well-thought-of and planned personality dimension. Personality traits, which mostly occur spontaneously and randomly, form the basis of the interaction between human and object.

\section{The purpose and the importance of the research}

Determining personality traits in the branding of cities is seen as a very important strategic move. Within the framework of this research, it is aimed to reveal the attitudes towards the brand personality of the cities in the Eastern Black Sea Region and to contribute to the branding processes of the cities in the region. Thus, it will contribute to the branding processes of Eastern Black Sea Cities.

This study is important because it is one of the first studies on the brand personalities of cities in the Eastern Black Sea Region, after all, it is one of the first studies to measure the attitudes of residents living in these cities on the personalities of their own cities.

\section{The Scope and the method of the research}

This research was limited to city residents residing in cities that are members of the Eastern Black Sea Municipalities
Union. In this study carried out in city centers within the scope of Eastern Black Sea Provinces, the sample sizes were determined according to the population size of the cities. According to the research plan carried out; Questionnaires were applied to 270 in Trabzon and Ordu, 200 in Rize and Giresun, and 125 in Gümüşhane, Artvin and Bayburt. In this study, in which a total of 1,315 questionnaires were applied between May 2017 and July 2019, the questionnaires that were observed to be erroneous or not filled with seriousness were removed and the remaining 1,221 questionnaires were analyzed. In this study, the data collected by questionnaire technique were recorded in a statistics program and these data were subjected to frequency, $t$ test and one-way analysis of variance.

\section{The findings and Conclusion}

According to the results obtained from this study, in which personality suggestions related to each city considered as a sample besides the data obtained, cities do not have very unique personality characteristics. According to the results, it is seen that one of the personality traits that stands out in all cities, although the cities subject to the sampling are of different sizes, is the small city personality trait. The fact that Trabzon and Ordu city residents include the concept of small city among the personality traits of their cities is seen as one of the most important problems for these two cities. When the personality traits are examined, it is understood that the common characteristics of these cities are defined as family oriented, small city, traditional, safe, reliable and peaceful. In addition, perhaps the biggest problem for these cities, which are generally defined with positive personality traits, is that these cities do not have unique personality traits. A city that really wants to be a brand must first have a unique brand promise and a brand personality that is suitable for this promise. 